\section{Research Article}

(C) 2021 Zahra et.al.. This is an open access article licensed under the Creative Commons Attribution-NonCommercial 4.o International License (https://creativecommons.org/licenses/by-nc/4.o/)

Received: 12 September 2020 / Accepted: 2 December 2020/ Published: 17 January 2021

\title{
Media Exposure and Child Psychology: Parental Perceptions about Effects
}

\section{Muniba Fatima Zahra}

Doctoral Student of Media and Communication Studies, Faculty of Media and Communication Studies, University of Central Punjab, Khayaban-e-Jinnah Road, Johar Town, Lahore, Punjab, Pakistan

\section{Dr. Fawad Baig}

Associate Professor, Faculty of Media and Communication Studies, University of Central Punjab, Khayaban-e-Jinnah Road, Johar Town, Lahore, Punjab, Pakistan

\section{Prof. Dr. Taimoor-ul Hassan}

Dean, Faculty of Media and Communication Studies, University of Central Punjab, Khayaban-e-Jinnah Road, Johar Town, Lahore, Punjab, Pakistan

DOI: https://doi.org/10.36941/ajis-2021-oo1o

\section{Abstract}

This study explores the effect of media exposure on child's psychology according to parental perceptions. Aggression and self-concept are selected as parameters of children psychology. The combined role of education and occupation of mothers as moderators in relationship between media exposure and children's psychology are also analyzed. A survey was conducted with 400 parents of school going children aged between 6 to 12 years. The results show positive association of media exposure with psychology, self-concept and aggression among children according to their parents. Furthermore, the education of mother moderates the relation between media exposure and self-concept positively, while mother's occupation does not moderate this relationship. The results also indicate that mother's education negatively moderates the relationship between media exposure and aggression among children, however the occupation of mother positively moderates this relation. This study concludes that there is a strong effect of media exposure on children psychology as perceived by their parents.

Keywords: Media exposure, Child's psychology, Self-concept, Aggression, Mother's education, Mother's occupation

\section{Introduction}

Media play an essential role in increasing public attention, formulating their opinion about issues (Soumi, 2016) and link them to the rest of the world (Dwivedi \& Pandey, 2013). Media is a dominant change agent (Strasburger \& Hogan, 2013), and television particularly plays an important 
role as an educator, informer, and entertainer for children (Swinburn \& Shelly, 2009).

Education in early childhood is important for kids' holistic growth (social, emotional, cognitive and physical). Whatever children watch or read in early childhood has an impression on their mind and they use and apply their early childhood learning throughout their lives (Burke, 20oo; Evans, Myers, \& Ilfeld, 2000; Penn, 200o). For this reason, various nations have sizeable funding for children's training and education in early age. Numerous global institutes and organizations suggested that children must get equal opportunities of learning in their childhood for their development and progress (Lasi, Nadeem, \& Fatima, 2007). Malik, Hassan and Sultana (2004) claimed that electronic media inspire and reinforce latent attitude and formulate new attitudes among children. TV is responsible for creating meanings of the world around them (Guru, Nabi, \& Raslana, 2013).

The effects of television on children's attitudes and behavior, and the relationship of TV viewing with their physical and psychological wellbeing have been the focus of studies in mass media research (Bushman \& Huesmann, 2014; Heather, Ellen, \& Daniel, 2008). Pakistani electronic media has become more vibrant and independent since 2002 when it was liberalized during the martial law of General Pervez Musharraf. Now, the number of TV channels have increased from single state-owned television network of Pakistan Television (PTV) Corporation Limited to more than 9o satellite TV channels in Pakistan (Pakistan Electronic Media Regularity Authority, 2019). State owned channel PTV Home telecasts one-hour children's transmission daily. Previously, Indus Vision had a children programming slot called Indus Chotu. In 2008, TV channel WikKid Plus was launched for children but due to financial issues it had to be shut down. Currently, three global children's channels namely Cartoon Network, Nickelodeon, and Disney have landing rights to broadcast content for children in Pakistan (Khan, 2018).

In addition to television channels, new ways of dissemination of already aired children content, like YouTube channels, have also emerged. This has led to an increased exposure of children to TV content. Previously, many studies have made an effort to investigate the effects of media exposure on aggression, while there are few studies which have evaluated the impact of media exposure on selfconcept. Most of these studies have been done in the western context (Rivadeneyra, Ward, \& Gordon, 2007; Subervi-Vélez \& Necochea, 2009; Tin et al., 2012). There is a dire need to de-westernize this area of research (see Park \& Curran, 200o). Moreover, very few studies have explored parental perceptions about the effects of TV content on children's behavior, cognition and mental development (see Boobalakrishnan \& Pichandy, 2017; Nathanson, Sharp, Aladé, Rasmussen, \& Christy, 2013; Rideout, Vandewater, \& Wartella, 2003).

In the Pakistani context, some studies have investigated the effects of TV content on aggression among children (Hassan \& Daniyal, 2013; Mahsud, Rawan, \& Yaser, 2009; Yousaf, Shehzad, \& Hassan, 2015), their language and culture (Ahsan, Bajwa, Bashir, \& Sehar, 2015; Anis, Ashfaq, \& Mujtaba, 2012), and religious values (Maqsood \& Amer, 2014; Nasir \& Malik, 2014). None of these studies has explored the effects of TV content on the self-concept of children in Pakistan. Furthermore, very few research studies have explored the perceptions of Pakistani parents about the effects of TV content on children (Abideen \& Salaria, 2010; Mahmood, 2017) but not any of them is related to children's aggression and self-concept. This paper focuses on the impact of TV content on psychology (self-concept and aggression) of Pakistani children according to parental perceptions. Also, it discovers the role of mother's education and occupation as moderators in relationship between media exposure and children's psychology.

Researches on positive effects of media suggest that media content designed with an educational purpose has positive effects on the learning of children (Heather, Ellen, \& Daniel, 2008; Kirkorian \& Anderson, 2008; Lee \& Huston, 2003). Media can play the role of an educator for children as television is an omnipresent force in children's lives at present (Jordan, 2011).

Television content for children is not only affecting their moral, cultural, and social values but the psyche and intellect of children too (Roberts \& Powell III, 2014). However, the present study focuses only on psychology (self-concept and aggression) of children. It emphasizes on the cognitive and behavioral development of kids from pre-birth to teenage and covers the physical, social and 
intellectual growth of children. There are various factors which affect the psychological development of children, and media is one of them (Cherry, 2020). Psychology deals with five domains i.e. biological, cognitive, developmental, social and personality, mental and physical health (Gurung et al., 2016). This study deals with social and emotional psychology, as self-concept and aggression fall under this category. Self-concept is the central point for children's personality grooming and development. In infancy stage, children start to develop their self-concept, which further defines their characteristics, capabilities and attitudes. Self-concept is a common word that denotes how someone considers, estimates or identifies oneself and what kind of idea a person has about oneself (McLeod, 2008). This study also finds its roots in cultivation theory (Gerbner, Gross, Morgan, \& Signorielli, 1986) which divides viewers in two categories of light viewers and heavy viewers, and hypothesizes that heavy viewers are more affected by media.

\section{Literature Review}

\subsection{Media Exposure and Child Psychology}

Kostyrka-Allchorne, Cooper and Simpson (2017) found a complex relationship between media exposure and child psychology. The effects of media exposure were dependent on respondents' own attributes, their family and surroundings (society), and also the type of content they watch on television. Wheeler (2015) also inferred that TV viewing affects the psychology of children significantly but the nature of effects depends upon the content which is being watched. Comer et al. (2008) inferred that the more children watch television, the more their psyche is affected. According to Mares and Woodard (2005), prosocial use of media affects child socialization and the type of content affects psychology of children.

\subsection{Media Exposure and Self-Concept}

Television viewing affects the self-concept and personality growth of children both positively and negatively. On the negative side, TV made children fearful, aggressive and obese, and on the positive side, it helped a lot in terms of learning new innovative things in the age of globalization (Mares \& Kretz 2015). Relation between TV viewing and self-concept is J inverted (Tin et al., 2012). However, according to Jackson, Von Eye, Fitzgerald, Zhao and Witt (2010), different kinds of media forecast dimensions of self-concept and self-esteem differently. For example, videogames negatively affect selfconcept, while TV and Internet have positive effect. According to Subervi-Vélez and Necochea (2009), Spanish language TV programs consumption was not significantly associated with self-concept. Active selection of TV content is linked with poor self-concept of children. According to Rivadeneyra, Ward and Gordon (2007), media consumption is negatively linked with self-concept and self-esteem. Though media consumption has negative association with self-concept, it varies from genre to genre (Ward, 2004). Anderson and Bushman (2002) concluded that violent media content temporarily changes the self-concept. Self-concept is affected by other variables too, like working mothers make their children self-sufficient, confident, and give them social awareness and sense of commitment and struggle thus working mothers build a better self-concept among their children (Singh, 2018; Sultana \& Noor, 2012). A study found that mother's education level is positively associated with positive self-concept (Ward, 2004). According to Gutman (1973), heavy viewers are more informed about their self-concept. In addition, family setup plays positive role in the construction of self-concept (Walgito, 2010). No study is conducted related to the self-concept of Pakistani children. Keeping in view the aforementioned studies, following hypotheses have been formulated in the Pakistani context:

H1. There is a significant association between children's media exposure and perceived effects on their psychology.

H2. There is positive relationship between children's media exposure and self-concept.

H3. There is difference between the self-concept of light and heavy viewers.

It is a universal truth that children are more connected to their mothers as compared to fathers 
because they spend most of their time with mothers. Similarly, upbringing of a child is considered to be mothers' responsibility in most of the developing countries like Pakistan. This is why education and occupation of a mother also affect the children (Almani, Abro, \& Mugheri, 2012). Hence, following hypotheses have been made:

H4. Education of mother positively moderates the relationship between media exposure and selfconcept of children.

H5. Occupation of mother serves as a positive moderator between the relationship of media exposure and self-concept of children.

\subsection{Media Exposure and Aggression}

Aggression is a kind of behavior that is used to damage another person who does not desire to be hurt (Anderson \& Bushman, 2002; Baron \& Richardson, 2004; Bushman \& Huesmann, 2014). Violence shown on media have a strong effect on students' mind and they become more prone to aggressive behavior (Jahan \& Khan, 2017; Tanwar \& Priyanka, 2016). Amount of time spent in viewing media screen along with parents, their education and surroundings have a great impact on child's indulgence/deviation drifted toward violence and aggression (Wiedeman, Black, Dolle, Finney, \& Coker, 2015). TV cartoons create aggressive behavior in school going children (Odukomaiya, 2014). Similarly, various studies (Huesmann \& Taylor, 2006; Rawlings, 2011) inferred that violent TV programs negatively affect children's behaviors and make them more aggressive and relatively anti-social. Likewise, they are exposed to different type of violence through TV, films, video games and even in their real life. All this exposure resulted in cultivating aggression in the behavior of adolescents. High level of exposure to violence made students more desensitized (Funk, Baldacci, Pasold, \& Baumgardner, 2004).

Rosenkoetter, Rosenkoetter, Ozretich and Acock (2004) maintained that children who were not exposed to violent media content were less aggressive. Several studies related to adolescents maintained that higher media exposure to violent content resulted in physical fights and arguments with peers, teachers and parents that ultimately lead to lower academic performance (Anderson \& Bushman, 2002; Bushman \& Huesmann, 2014; Hauge \& Gentile, 2003; Kenyon, 2002; Villani, 2001; Slater, Henry, Swaim, \& Anderson, 2003). Slater (2003) revealed that aggressive children try to use aggressive media content either films, video games, TV programs or websites. However, according to Greitemeyer (2011) media exposure sometimes have no effect on aggression and prosocial media exposure tend to decrease the aggression among children.

Jamal, Govil and Gupta (2018) found in their study related to senior secondary school students that there is no association between the education of mother and children's aggressive behavior. Moreover, children of working mothers behave more aggressively than the children of non-working mothers. Tremblay et al. (2004) found that children belonging to low income families behave more aggressively and they learnt aggressive behavior in infancy time period. For children who could not overcome their physical aggressive behavior, there were more chances that their mothers had been anti-social before their birth. In the Pakistani context, few studies (Hassan \& Daniyal, 2013; Yousaf, Shehzad, \& Hassan, 2015; Mahsud, Rawan, \& Yaser, 2009) have inferred that cartoons and children content instill aggressiveness in children as they get more attracted toward the violence shown in cartoons and movies. None of these studies focused on parental perception regarding the effects of TV content on aggression among children. Furthermore, the role of education and occupation of Pakistani mother as moderating variable is also not explored. Keeping in view the aforementioned studies, following hypotheses have been formulated:

H6. There is relationship between media exposure and aggression among children.

H7. There is difference between the aggression of light and heavy viewers.

H8. Education of mother negatively moderates the relationship between children's media exposure and aggression.

H9. Occupation of mother positively moderates the relationship between children's media exposure and aggression. 


\section{Method}

In order to determine the effect of media exposure on children's psychology according to parental perceptions, a survey $(N=400)$ was conducted among children's parents from December 2019 to February 2020.

\subsection{Survey}

A questionnaire comprised of four sections i.e. demographic information, media exposure, selfconcept, and aggression was prepared to collect data from the respondents. After developing an initial questionnaire, a pilot study was conducted to check the reliability of the instrument. For this purpose, data was collected through questionnaire from 50 parents, and the Cronbach's alpha values of two main constructs self-concept and aggression were .86 and .88 respectively.

\subsection{Sample}

The data was collected from the parents of school going children aged between 6 to 12 years living in Lahore city of Pakistan. Participants were selected through multistage sampling. At the first stage, four towns of Lahore city were selected through systematic sampling and the list of towns was obtained from the official website of The Local Government \& Community Development Department, Government of the Punjab (2017) and every second town in the list was selected. At the second stage, list of all union councils (UCs) was obtained from the same website. Every 5 th UC was selected through systematic sampling thus 26 union councils were selected, and 20 parents of children were selected from each UC. Total 520 questionnaires were distributed among parents and 460 were received back. All those questionnaires which were inappropriately filled and had missing values were rejected. Thus, 400 questionnaires were considered final (Response rate $=76.9 \%$ ).

\subsection{Measures}

Media exposure was an independent variable while child psychology, self-concept, and aggression were dependent variables. Education and occupation of mother were taken as moderating variables in this study.

\subsubsection{Media Exposure}

Media exposure was measured by the amount of time children spent on watching TV during weekdays and weekends on the consent of their parents. The response categories included less than one hour, 1 to 2 hours, 2-3 hours, 3-4 hours and more than 4 hours. This approach has been used reliably to measure media exposure of children by many researchers (see Anderson, Gentile, \& Buckley, 20o6; Gentile, Reimer, Nathanson, Walsh, \& Eisenmann, 2014).

\subsubsection{Self-Concept}

To measure the self-concept of children this study adapted Adolescents' Self-Concept Short Scale, a version of Piers-Harris Children's Self-Concept Scale (PHCSCS), developed by Veiga and Leite (2016). Five subscales (Anxiety, behavior, popularity, happiness, and intellectual status) with 25 items were used, and Cronbach's alpha was .86 (Anxiety $=.90$, behavior $=.78$, popularity $=.87$, happiness $=.76$, and intellectual status $=.71$ ). All the values from these subscales were computed and the minimum recorded score was 60 while maximum was 121. The scale consisted of items such as, "My child gets nervous when the teacher calls him", and "My child is among the last to be chosen for games" etc. The responses for each statement were recorded on a five point Likert scale, where $1=$ strongly disagree; 2 = disagree; 3 = neutral; 4 = agree; and 5 = strongly agree. 


\subsubsection{Aggression}

To measure aggression among children, a tool for aggression developed by Buss and Perry (1992) was adapted. This scale consisted of 3 sub-scales (Physical aggression, verbal aggression, and anger) with 18 items, and Cronbach's alpha was .88 (Physical aggression $=.86$, verbal aggression $=.76$, and anger $=$ .90). All the values from these subscales were computed and the minimum recorded score was 18 while maximum was 107. The scale consisted of items such as, "My child get into fights a little more than the average person", and "My child is short-tempered" etc. The responses for each statement were recorded on a five point Likert scale, where $1=$ strongly disagree; $2=$ disagree; $3=$ neutral; $4=$ agree; and $5=$ strongly agree.

\subsubsection{Child Psychology}

Child psychology was measured by computing the constructs self-concept and aggression. All the values from the sub-scales of these two constructs were computed and the minimum recorded score was 78 while maximum was 199 .

\section{Findings and Discussion}

Demographic characteristics of the sample showed that the majority of respondents were educated and working class mothers $(257,64.3 \%)$, and among them $212(53 \%)$ were aged between 31 to 40 years. There were $143(35.8 \%)$ fathers among respondents, and $75(52.4 \%)$ of them were aged between 41 to 50 years. Majority of reported children $(265,66.3 \%)$ were boys and aged between 5 to 8 years studying from class 1 to 4 .

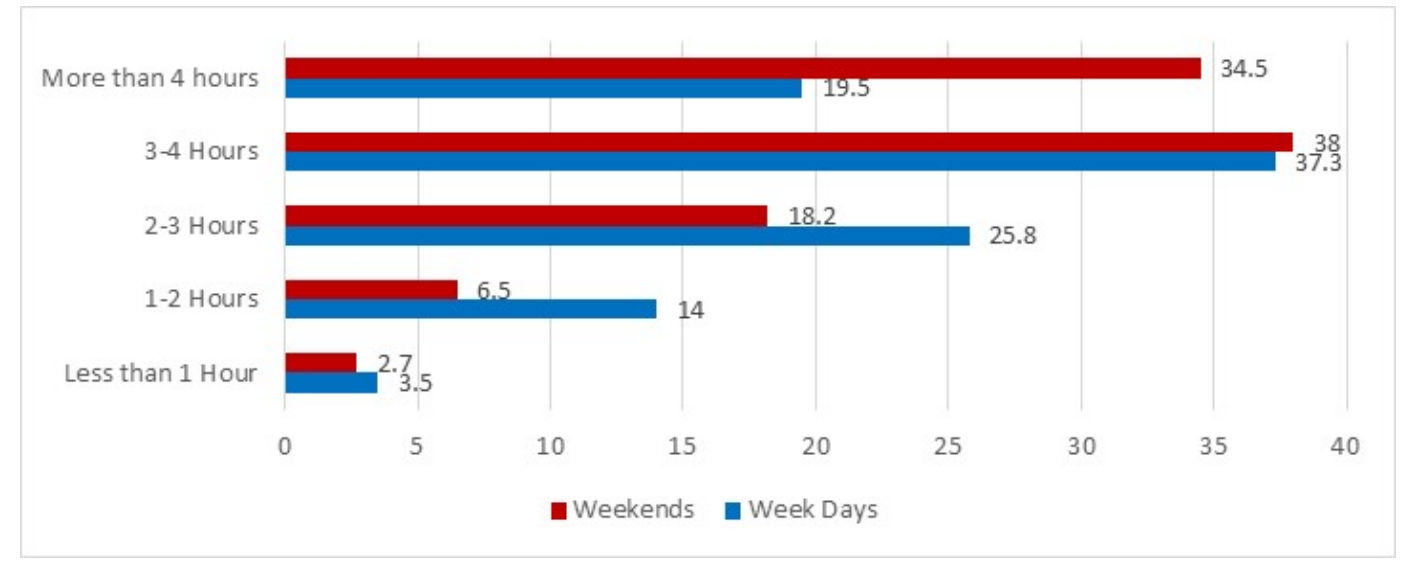

Figure 1. Media exposure of children on weekdays and weekends

Figure 1 represents the time spent by children in front of TV during weekdays and weekends. According to the data, majority of children (weekdays $=149(37.3 \%)$, weekends $=152(38 \%)$ ) spent 3 to 4 hours in front of television to watch their programs. However, 138 (34.5\%) children watched TV on weekends and $78(19.5 \%)$ during weekdays for more than 4 hours. $14(3.5 \%)$ children spent less than 1 hour to watch their programs during weekdays while $11(2.7 \%)$ on weekends. It is evident from the findings that children spent more time with TV during weekends. 
Table 1. Children's frequency of watching different programs on TV channels

\begin{tabular}{lccccc}
\hline & Never & $\begin{array}{c}\text { Rarely } \\
1-2 \text { days }\end{array}$ & $\begin{array}{c}\text { Sometimes } \\
\text { 3 days }\end{array}$ & $\begin{array}{c}\text { Frequently } \\
4-5 \text { days }\end{array}$ & $\begin{array}{c}\text { Very Frequently } \\
6-7 \text { days }\end{array}$ \\
\hline Cartoons & $36(9.0)$ & $74(18.5)$ & $82(20.5)$ & $88(22.0)$ & $120(30.0)$ \\
Movies & $15(3.8)$ & $49(12.3)$ & $92(23.0)$ & $143(35.8)$ & $101(25.3)$ \\
Dramas & $77(19.3)$ & $116(29.0)$ & $116(29.0)$ & $86(21.5)$ & $05(1.3)$ \\
Quiz shows & $56(14.0)$ & $119(29.8)$ & $112(28.0)$ & $77(19.3)$ & $36(9.0)$ \\
Travelogues & $61(15.3)$ & $126(31.5)$ & $120(30.0)$ & $80(20.0)$ & $13(3.3)$ \\
Sci. \& Art Shows & $58(14.5)$ & $110(27.5)$ & $119(29.8)$ & $88(22.0)$ & $25(6.3)$ \\
Reality shows & $55(13.8)$ & $113(28.3)$ & $95(23.8)$ & $128(32.0)$ & $09(2.3)$ \\
\hline
\end{tabular}

$N=400$

Table 1 depicts the percentage of children's frequency of watching different genres on TV channels according to their parents. Results show that children watched cartoon and movies frequently on channels instead of quiz shows, travelogues, science, and art shows.

Table 2. Pearson product moment correlation coefficient of children's media exposure, child psychology, self-concept and aggression

\begin{tabular}{lccc}
\hline Variables & Child Psychology & Self-Concept & Aggression \\
\hline Media Exposure & $.574^{* *}$ & $.168^{* *}$ & $.643^{* * *}$ \\
\hline Correlation: ${ }^{* *} p<.01,{ }^{* * *} p<.001$ & & &
\end{tabular}

Pearson Product Moment Correlation Coefficient was employed to find relationship among media exposure, child's psychology, self-concept and aggression, and to test $\mathrm{H}_{1}, \mathrm{H}_{2}$ and H6. Table 2 indicates a positive relation between media exposure and child psychology. The results suggest that due to increased media exposure, child's psychology also developed accordingly. This finding validates $\mathrm{H}_{1}$, and is in line with previous researches by Comer et al. (2008), Kostyrka-Allchorne, Cooper and Simpson (2017), Mares and Woodard (2005), and Wheeler (2015) who reported that media exposure affects the psychology of children significantly.

Table 2 further indicates a positive relationship between media exposure and self-concept. In addition, children's increased media exposure brought change in their self-concept. This result validates $\mathrm{H}_{2}$, and is consistent with the findings of Mares and Kretz (2015) that media have negative as well as positive effect on children's self-concept. On the negative side, it can make children fearful, aggressive and obese; while on the positive side, it helped them a lot in terms of learning new and innovative things. This result is also aligned with the findings of Tin et al. (2012) that a J inverted relation exists between TV viewing and self-concept. Anderson and Bushman (2002) also concluded that violent media content temporarily changes the self-concept. On the other hand, this finding is opposite to the research findings of Rivadeneyra, Ward and Gordon (2007) and Subervi-Vélez and Necochea (2009) who found that media use had negative effect on self-concept. One possible reason of this contradiction could be the type of content which children watch on TV.

Table 2 indicates a positive relationship between media exposure and aggression, which means that with the increase of media exposure, aggression among children was also increased as reported by the parents. This finding not only validated $\mathrm{H} 6$ but is also consistent with the findings of some other researches (see Funk, Baldacci, Pasold, \& Baumgardner, 2004; Odukomaiya, 2014; Wiedeman, Black, Dolle, Finney, \& Coker, 2015). 
Table 3. Difference of self-concept and aggression between heavy and light viewers

\begin{tabular}{|c|c|c|c|c|c|c|c|c|c|}
\hline \multirow{2}{*}{ Variable } & \multicolumn{2}{|c|}{$\begin{array}{c}\text { Light Viewers } \\
(\mathrm{n}=173)\end{array}$} & \multicolumn{2}{|c|}{$\begin{array}{l}\text { Heavy Viewers } \\
(\mathrm{n}=\mathbf{2 2 7})\end{array}$} & \multirow[b]{2}{*}{$t(400)$} & \multirow[b]{2}{*}{$p$} & \multicolumn{2}{|c|}{$95 \% C I$} & \multirow{2}{*}{ Cohen's d } \\
\hline & $M$ & SD & $M$ & $S D$ & & & $L L$ & $U L$ & \\
\hline Self-concept & 87.56 & 15.55 & 93.52 & 14.96 & -3.882 & .000 & -8.984 & -2.943 & 0.390 \\
\hline Aggression & 44.04 & 14.72 & 47.39 & 14.65 & 2.261 & .024 & .437 & 6.269 & 0.227 \\
\hline
\end{tabular}

Note. $\mathrm{CI}=$ Confidence Interval, $L L=$ Lower Limit, $U L=$ Upper Limit.

Independent sample $t$ test was applied to check the difference between the self-concept and aggression of light and heavy viewers and to test $\mathrm{H}_{3}$ and $\mathrm{H}_{7}$. The results showed that there was significant difference between the self-concept of light viewers and heavy viewers. The findings showed that the self-concept of heavy viewers $(M=93.52, S D=14.96)$ is more developed as compared to light viewers $(M=87.56, S D=15.55), t(400)=-3.882, p<.05, d=0.390$. This result not only confirmed $\mathrm{H}_{3}$ but is also in line with Gutman (1973) who reported that heavy viewers are more informed about their selfconcept. Table 3 also indicates that heavy viewers $(M=47.39, S D=14.65)$ behaved more aggressively as compared to light viewers $(M=44.04, S D=14.72), t(400)=2.261, p<.05, d=0.227$, and this result supported $\mathrm{H}_{7}$.

Table 4. Hierarchical moderated regression model of self-concept

\begin{tabular}{|c|c|c|c|c|c|c|}
\hline \multirow[b]{2}{*}{ Variables } & \multicolumn{2}{|c|}{ Basic model } & \multicolumn{2}{|c|}{ Moderation Model } & \multicolumn{2}{|c|}{ Extended Model } \\
\hline & Std. $\beta$ & $t$-values & Std. $\beta$ & $t$-values & Std. $\beta$ & $t$-values \\
\hline M.E. & .168 & $3 \cdot 392^{* * *}$ & .062 & .592 & -.709 & $-2.223^{*}$ \\
\hline M.E x Edu. & & & .182 & $2.249^{* *}$ & 1.035 & $4.070^{* * *}$ \\
\hline M.E x Occ. & & & -.045 & -.699 & .142 & .645 \\
\hline Edu. & & & & & -.635 & $-3.579^{* * *}$ \\
\hline Occ. & & & & & -.152 & -.888 \\
\hline$R^{2}$ Self-con. (\%) & .028 & & .106 & & .180 & \\
\hline$\Delta R^{2}$ Self-con. (\%) & & & .078 & & .074 & \\
\hline
\end{tabular}

Table 4 reveals that media exposure had significant positive effect on self-concept $(\beta=.168, t=3.392$, $p<0.001)$. Results also indicated that media exposure and education of mother collectively had significant positive effect on the self-concept of children $(\beta=.182, t=2.249, p<0.01)$. Findings suggested that media exposure and occupation of mother had no significant effect on self-concept. Moreover, occupation of mother did not serve as a moderator between media exposure and self-concept. The addition of moderating variables increased the explained variance of self-concept considerably $\left(R^{2}=.106\right)$. The education of mother as moderating variable significantly affected the self-concept of children $(\beta=-.635 t=-3.579, p<0.001)$, whereas the occupation of mother did not have any significant effect on children's self-concept. These variables directly increased the variance of self-concept $\left(R^{2}=.180\right)$.

These results confirmed $\mathrm{H}_{4}$, and also supported Ward's (2004) findings that mother's education level was positively associated with self-concept of children. However, the occupation of mother did not serve as a moderator between media exposure and self-concept. Thus, $\mathrm{H}_{5}$ was not supported by the findings of this study. 
Table 5. Hierarchical moderated regression model of aggression

\begin{tabular}{lcccccc}
\hline & \multicolumn{2}{c}{ Basic model } & \multicolumn{2}{c}{ Moderation Model } & \multicolumn{2}{c}{ Extended Model } \\
\cline { 2 - 7 } Variables & Std. $\beta$ & $t$-values & Std. $\beta$ & $t$-values & Std. $\beta$ & $t$-values \\
\hline M.E. & .643 & 3.562 & .127 & 1.235 & .888 & $2.802^{* *}$ \\
M.E x Edu. & & & -.414 & $-5.205^{* * *}$ & -1.277 & $-5.059^{* * *}$ \\
M.E x Occ. & & .166 & $2.621^{* *}$ & .069 & .318 \\
Edu. & & & & .643 & $3.651^{* * *}$ \\
Occ. & & & .079 & .464 \\
$R^{2}$ Aggression (\%) & .003 & .135 & .191 & .056 \\
$\Delta R^{2}$ Aggression $(\%)$ & & .132 & & \\
\hline Notes: ${ }^{*} p<0.05 ;{ }^{* *} p<0.01 ;{ }^{* * *} p<$ o.oo1; M.E: Media Exposure; Edu.: Education of Mother; Occ.: Occupation of Mother \\
\hline
\end{tabular}

Media exposure had significant association with aggression among children $(\beta=.643, t=3.562, p<0.001)$ (see Table 5). Moreover, findings indicated that media exposure and education of mother had significantly affected aggression among children $(\beta=-.414, t=-5.205, p<0.001)$. Furthermore, outcomes demonstrated that the occupation of mother moderated the relationship between media exposure and aggression. This interactive effect was significant $(\beta=.166, t=2.621, p<0.01)$. The addition of moderating variables increased the explained variance of aggression $\left(R^{2}=.135\right)$.

Results further showed that the education of mother significantly affected the aggression among children $(\beta=.643 t=3.651, p<0.001)$. However, the occupation of mother did not have any significant effect on it. These variables directly increased the variance of self-concept $\left(R^{2}=.191\right)$.

These results supported $\mathrm{H} 8$ and indicated that media exposure and education of mother had negative effect on aggression among children. Thus, it could be inferred that education of mother played an important role to control the aggression among children. The more educated the mother is, the more it controlled the aggression among children. This result is consistent with the findings of Wiedeman, Black, Dolle, Finney and Coker (2015) who found that various factors including age, gender, amount of time spent in viewing media screen as well as the role of parents, their education and surroundings had a great impact on child's indulgence toward violence and aggression.

Additionally, $\mathrm{H}_{9}$ was confirmed by the findings of this study (see Table 5). This study suggested that the occupation of mother moderates the relationship between media exposure and aggression among children. It means that if a mother is educated then media exposure cannot increase aggression in children. However, if a mother is working lady then due to her busy schedule she may ignore her children and cause a gradual increase in their aggression.

\section{Conclusion}

The study confirms the notion that media exposure has positive effect on Pakistani children's psychology. The results indicated a positive relation between media exposure, self-concept and aggression among Pakistani children. The moderating role of education of mother in media exposure and psychology (self-concept and aggression) is also validated by the study. It positively affected the self-concept and negatively affected aggression among children. However, occupation of mother has two different effects: there is no effect on self-concept of children and has positive effect on media exposure and aggression relationship.

The future researchers may explore different research designs including experimental, content analysis and observational research. More variables like social effects, behavioral and cognitive effects of children content on adolescents may also be studied. 


\section{References}

Abideen, Z. \& Salaria, M. R. (2010, January). Effects of television advertising on children: With special reference to Pakistani urban children. Paper presented at the 1oth National Research Conference, SZABIST, Islamabad, Pakistan.

Ahsan, A., Bajwa, N., Bashir, S., \& Sehar. (2015). Effects of Indian cartoons on children's language and their changing behaviour. (Unpublished Research Report). Punjab University, Lahore, Pakistan.

Almani, A. S., Abro, A., \& Mugheri, R. A. (2012). Study of the effects of working mothers on the development of children in Pakistan. International Journal of Humanities and Social Science, 2(11), 164-171.

Anderson, C. A., \& Bushman, B. J. (2002). The effects of media violence on society. Science, 295(5564), 2377-2379. https//doi.org/10.1126/science.1070765

Anderson, C. A., Gentile, D. A., \& Buckley, K. E. (2006). Violent video game effects on children and adolescents. Theory, research, and public policy. New York, NY: Oxford University Press.

Anis, F., Ashfaq, A., \& Mujtaba, A. (2012). Promotion of Hinduism in children through cartoons in Pakistan. Crosscultural Communication, 8(1), 86-90.

Baron, R. A., \& Richardson, D. R. (2004). Human aggression. Berlin, Germany: Springer Science \& Business Media.

Boobalakrishnan, N., \& Pichandy, C. (2017). Parental intervention and frequency of mediation styles towards children watching television in India. Media Watch, 8(2), 247-257. https://doi.org/10.15655/mw/2017/v8i2/49007

Burke, J. (2000, October 29). Broken victims of a Nasty little war seek refuge in the swollen slums. The Observer. Retrieved from https://www.theguardian.com/world/20oo/oct/29/jasonburke.theobserver

Bushman, B. J., \& Huesmann, L. R. (2014). Twenty-five years of research on violence in digital games and aggression revisited: A reply to Elson and Ferguson (2013). European Psychologist, 19(1), $47-55$. https://doi.org/10.1027/1016-9040/aooo164

Buss, A. H., \& Perry, M. (1992). The aggression questionnaire. Journal of Personality and Social Psychology, 63(3), 452-459. https://doi.org/10.1037/oo22-3514.63.3.452

Cherry, K. (2020). The origins of Psychology: From philosophical beginnings to the modern day. Retrieved from https://www.verywellmind.com/a-brief-history-of-psychology-through-the-years-2795245

Comer, J. S., Furr, J. M., Beidas, R. S., Babyar, H. M., \& Kendall, P. C. (2008). Media use and children's perceptions of societal threat and personal vulnerability. Journal of Clinical Child E Adolescent Psychology, 37(3), 622-63o. https://doi.org/10.1080/15374410802148145

Dwivedi, P. K. \& Pandey, I. (2013). Role of media in social awareness. International Journal of Humanities and Social Sciences, 1(1), 67-70.

Evans, J. L., Meyers, R. G., \& Ilfeld, E. (200o). Early childhood counts: A programming guide on early childhood care for development. Washington DC, USA: World Bank Publications.

Funk, J. B., Baldacci, H. B., Pasold, T., \& Baumgardner, J. (2004). Violence exposure in real-life, video games, television, movies, and the internet: is there desensitization? Journal of adolescence, 27(1), 23-39.

Gentile, D. A., Reimer, R. A., Nathanson, A. I., Walsh, D. A., \& Eisenmann, J. C. (2014). Protective effects of parental monitoring of children's media use: A prospective study. JAMA pediatrics, 168(5), 479-484.

Gerbner, G., Gross, L., Morgan, M., \& Signorielli, N. (1986). Living with television: The dynamics of the cultivation process. In J. Bryant \& D. Zillman (Eds.), Perspectives on media effects (pp. 17-40). Hilldale, NJ: Lawrence Erlbaum Associates.

Government of the Punjab. (2017, August 22). The Punjab gazette (Extra ordinary issue). Retrieved from https://lgcd.punjab.gov.pk/system/files/MCLZones_o.pdf

Greitemeyer, T. (2011). Effects of prosocial media on social behavior. Current Directions in Psychological Science, 20(4), 251-255. https://doi.org/10.1177/0963721411415229

Guru, B. P., Nabi A., \& Raslana, R. (2013). Role of television in child development. Journal of Mass Communication E Journalism, 3(3). https://doi.org/10.4172/2165-7912.1000153

Gurung, R. A., Hackathorn, J., Enns, C., Frantz, S., Cacioppo, J. T., Loop, T., \& Freeman, J. E. (2016). Strengthening introductory psychology: A new model for teaching the introductory course. American Psychologist, 71(2), 112124. https://doi.org/10.1037/aoo40012

Gutman, J. (1973). Self-concepts and television viewing among women. Public Opinion Quarterly, 37(3), 388397. https://doi.org/10.1086/268100

Hassan, A., \& Daniyal, M. (2013). Cartoon network and its impact on behavior of school going children. International Journal of Management, Economics and Social Sciences, 2(1), 6-11.

Hauge, M. R., \& Gentile, D. A. (2003, April). Video game addiction among adolescents: Associations with academic performance and aggression. Paper presented at Society for Research in Child Development Conference, Tampa, FL. USA, 24-27 April 2003. 
Heather L. K., Ellen A.W., \& Daniel R. A. (2008). Media and young children's learning. The Future of Children, 18(1), 39-61.

Huesmann, L. R., \& Taylor, L. D. (2006). The role of media violence in violent behavior. Annual Review of Public Health, 27, 393-415.

Jackson, L. A., von Eye, A., Fitzgerald, H. E., Zhao, Y., \& Witt, E. A. (2010). Self-concept, self-esteem, gender, race and information technology use. Computers in Human Behavior, 26(3), 323-328.

Jahan, A., \& Khan, I. A. (2017). The effect of violence in media on the school students: an exploratory study. Innovative Thoughts International Research Journal, 5(2), 41-55.

Jamal, A. Govil, D. P., \& Gupta, D.S. (2018). Aggression among adolescents: A study. International Journal of Social Relevance \& Concern, 6(4), 6-16.

Jordan, A. B. (2011). Children's media policy: International perspectives. Journal of Children and Media, 5(1), 1-3. https://doi.org/10.108o/17482798.2011.533478

Kenyon, B. J. (2002). The effects of televised violence on students (Unpublished masters' thesis), Grand Valley State University, Grand Rapids, Michigan, USA.

Khan, T.A., (2018, January 19). Why are there no TV channels for children in Pakistan? [Blog post]. Retrieved from http://blogs.dunyanews.tv/19633/

Kirkorian, H. L., \& Anderson, D. R. (2008). Learning from educational media. In S. L. Calvert \& B. J. Wilson (Eds.), The handbook of children, media, and development (pp. 188-213). West Sussex, UK: Wiley-Blackwell.

Kostyrka-Allchorne, K., Cooper, N. R., \& Simpson, A. (2017). The relationship between television exposure and children's cognition and behaviour: A systematic review. Developmental Review, 44, 19-58. https://doi.org/10.1016/j.dr.2016.12.002

Lasi, S., Nadeem, S., \& Fatima, I. (2007). Quality in early childhood education: Assessing early child development a holistic approach for ages 3-6 years. In S. Ali \& M. Rizvi (Eds.), Quality in education: Teaching and leadership in challenging times (pp. 295-305). Karachi, Pakistan: Aga Khan University Institute for Educational Development.

Lee, J. H., \& Huston, A. C. (2003). Educational televisual media effects. In E. L. Palmer \& B. M. Young (Eds.), The faces of televisual media: Teaching, violence, selling to children (pp. 83-106). Mahwah, NJ: Lawrence Erlbaum Associates, Inc., Publishers.

Mahmood, F. (2017). Role of dubbed Hindi cartoons in instilling Hindi linguistic pattern and culture among students (Unpublished M.Phil thesis). University of Central Punjab, Lahore, Pakistan.

Mahsud, N. M., Rawan, B., \& Yaser, N. (2009). The effects of TV cartoon network on the aggressive behaviour of school going children. Global Media Journal, 2(1). Retrieved from https://www.aiou.edu.pk/SAB/gmj /GMJ\%20Spring\%202009/Article_6.pdf

Malik, N. H., Hassan, M. Z. Y., \& Sultana, R. (2004). An impact of electronic media on the development of children's personality. Pakistan Journal of Life and Social Sciences, 2(2), 124-126.

Maqsood, Q., \& Amer, U. (2014). The effect of cartoons on young Pakistani children and it causing hindrance in their moral, social, lingual and religious development. (Unpublished Master's thesis). International Islamic University, Islamabad, Pakistan.

Mares, M. L., \& Kretz, V. (2015). Media effects on children. In J. D. Wright (Ed.), International encyclopedia of the social \& behavioral sciences (2nd ed., pp 35-41). Boston: Elsevier. https://doi.org/10.1016/B978-o-08-0970868.95006-2

Mares, M.-L., \& Woodard, E. (2005). Positive Effects of Television on Children's Social Interactions: A Meta Analysis. Media Psychology, 7(3), 301-322. https://doi.org/10.1207/S1532785XMEPo703_4

McLeod, S. (2008). Self-concept. Retrieved from https://www.simplypsychology.org/self-concept.html

Nasir, T., \& Malik, M. (2014). Impact of Hindu religious animated movie on children. Ma'arif Research Journal, 4(2), 17-28. Retrieved from http://mrjpk.com/impact-hindu-religious-animated-movie-children/

Nathanson, A. I., Sharp, M. L., Aladé, F., Rasmussen, E. E., \& Christy, K. (2013). The relation between television exposure and theory of mind among preschoolers. Journal of Communication, 63(6), 1088-1108. https://doi.org/10.1111/jcom.12062

Odukomaiya, E. I. (2014). Cartoons influence towards violence and aggression in school age children in Nigeria (Unpublished doctoral dissertation). Eastern Mediterranean University, Gazimağusa, North Cyprus.

Pakistan Electronic Media Regulatory Authority. (2019). List of satellite TV license issued by PEMRA. Retrieved from http://site.pemra.gov.pk/uploads/licensing/stv/list_of_licences_issued_stv.pdf

Park, M. J., \& Curran, J. (Eds.). (2000). De-westernizing media studies. London: Routledge. https://doi.org/10.4324/9780203981764

Penn, H. (200o). Early childhood services: Theory, policy and practice. Buckingham: Open University Press. 
Rawlings, B. T. (2011). Reaching an agreement: Effects of TV violence on youth (Unpublished master's thesis). Gonzaga University, Spokane, WA, USA.

Rideout, V. J., Vandewater, E. A., \& Wartella, E. A. (2003). Zero to six: Electronic media in the lives of infants, toddlers and preschoolers. Menlo Park, CA: Kaiser Family Foundation.

Rivadeneyra, R., Ward, L. M., \& Gordon, M. (2007). Distorted reflections: Media exposure and Latino adolescents' conceptions of self. Media Psychology, 9(2), 261-290.

Roberts, M. C., \& Powell III, J. L. (2014). Effects of television viewing on child development. Encyclopedia Britannica, inc. Retrieved from https://www.britannica.com/topic/effects-of-television-viewing-1995158\#ref324088

Rosenkoetter, L. I., Rosenkoetter, S. E., Ozretich, R. A., \& Acock, A. C. (2004). Mitigating the harmful effects of violent television. Journal of Applied Developmental Psychology, 25(1), 25-47.

Singh, L.K. (2018). Impact of working mothers on their children's development, Innovation the Research Concept, 3(3), 18-21.

Slater, M. D. (2003). Sensation-seeking as a moderator of the effects of peer influences, consistency with personal aspirations, and perceived harm on marijuana and cigarette use among younger adolescents. Substance Use E Misuse, 38(7), 865-880.

Slater, M. D., Henry, K. L., Swaim, R. C., \& Anderson, L. L. (2003). Violent media content and aggressiveness in adolescents: A downward spiral model. Communication Research, 30(6), 713-736.

Soumi, B. (2016). Mass media plays a crucial role in influencing people's mind. Retrieved from http://esolz.net/massmedia-plays-a-crucial-role-in-influencing-peoples-mind/

Strasburger, V. C., \& Hogan, M.J. (2013). Policy statement children, adolescents, and the media. Pediatrics, 132(5), 958-961.

Subervi-Vélez, F. A., \& Necochea, J. (2009). Television viewing and self-concept among Hispanic American children - a pilot study. Howard Journal of Communications, 2(3), 315-329. https://doi.org/10.1080/10646179009359723

Sultana, A. M., \& Noor, Z. (2012). Mothers' perception on the impact of employment on their children: Working and non-working mothers. IAMURE: International Journal of Social Sciences, 2, 113-131.

Swinburn, B., \& Shelly, A. (2009). Effects of TV time and other sedentary pursuits. International Journal of Obesity, 32(7), S132.

Tanwar, K. \& Priyanka. (2016). Impact of media violence on children`s aggressive behaviour. Indian Journal of Research. 5(6), 241-245.

Tin, S. P. P., Ho, D. S. Y., Mak, K. H., Wan, K. L., \& Lam, T. H. (2012). Association between television viewing and self-esteem in children. Journal of Developmental \& Behavioral Pediatrics, 33(6), 479-485.

Tremblay, R. E., Nagin, D. S., Seguin, J. R., Zoccolillo, M., Zelazo, P. D., Boivin, M., Daniel, P., \& Japel, C. (2004). Physical aggression during early childhood: Trajectories and predictors. Pediatrics, 114(1), e43-e5o. https://doi.org/10.1542/peds.114.1.e43

Veiga, F., \& Leite, A. (2016). Adolescents' self-concept short scale: A version of PHCSCS. Procedia - Social and Behavioral Sciences, 217, 631-637. https://doi.org/10.1016/j.sbspro.2016.02.079

Villani, S. (2001). Impact of media on children and adolescents: a 10-year review of the research. Journal of the American Academy of Child E Adolescent Psychiatry, 40(4), 392-401.

Walgito, B. (2010). Bimbingan dan Konseling. Yogyakarta, Indonesia: CV. Andi Offset.

Ward, L. M. (2004). Wading through the stereotypes: positive and negative associations between media use and black adolescents' conceptions of self. Developmental Psychology, 40(2), 284-294.

Wheeler, K. S. (2015). The relationships between television viewing behaviors, attachment, loneliness, depression, and psychological well-being (Unpublished honors thesis). Retrieved from https://digitalcommons.georgiasouthern.edu/honors-theses/98/

Wiedeman, A. M., Black, J. A., Dolle, A. L., Finney, E. J., \& Coker, K. L. (2015). Factors influencing the impact of aggressive and violent media on children and adolescents. Aggression and Violent Behavior, 25(Part A), 191198. https://doi.org/10.1016/j.avb.2015.04.008

Yousaf, D. Z., Shehzad, M., \& Hassan, S. A. (2015). Effects of cartoon network on the behaviour of school going children (a case study of Gujrat city). International Research Journal of Interdisciplinary E Multidisciplinary Studies (IRJIMS), 1(1), 173-179. 